\title{
Diasporic Second Language Englishes in the African Communities of Germany's Ruhr Area
}

\author{
Christiane Meierkord ${ }^{1}$, Bridget Fonkeu ${ }^{1} \&$ Eva Zumhasch ${ }^{1}$ \\ ${ }^{1}$ English Department, Ruhr-University Bochum, Germany \\ Correspondence: Christiane Meierkord, English Department, Ruhr-University Bochum, Universitätsstr. 150, \\ 44801 Bochum, Germany. Tel: 49-234-322-2590. E-mail: christiane.meierkord@rub.de
}

\author{
Received: October 29, 2014 Accepted: November 24, 2014 Online Published: January 27, 2015 \\ doi:10.5539/ijel.v5n1p1 URL: http://dx.doi.org/10.5539/ijel.v5n1p1
}

\begin{abstract}
The Ruhr Area is a metropolitan area located in the federal state of North Rhine-Westfalia in Germany. The region, which has a long history of migration and multilingualism, has recently attracted growing numbers of individuals who bring second language varieties of English to the area, which originate from postcolonial countries in Asia, on the African continent, or on the Indian subcontinent. African communities in particular form close-knit networks in the diaspora and engage in numerous associations, whilst at the same time maintaining ties with their original home countries. Their Englishes, both standardised and pidginised, which developed as a result of language contact in the respective home countries, are subject to a secondary language contact with German, resulting in further language change.

This paper describes the sociolinguistics of the various communities, before it documents the African communities' language preferences and discusses how the Englishes spoken in one individual community, Cameroon English and Cameroon Pidgin English, adapt in the new linguistic ecology. It argues that such diasporic Englishes pose important new territory for the study of English and offer opportunities to extend traditional frameworks towards integrating present-day societies' realities.
\end{abstract}

Keywords: diaspora, migration, Ruhr Area, West African

\section{Introduction}

In recent years, global migration has accelerated in a previously unknown manner, yielding contexts of super-diversity, which involve "an increased number of new, small and scattered, multiple-origin, transnationally connected, socio-economically differentiated and legally stratified immigrants" (Vertovec, 2007, p. 1024), and which are, as a result, characterised by very intricate patterns of language use (see below).

In many cases, migrating individuals are speakers of a postcolonial variety of English (Schneider, 2007). Whilst in the past such individuals tended to migrate into other English-speaking areas, many today settle in places where English has not traditionally been part of the linguistic ecology. One area which has recently witnessed growing in-migration of speakers of postcolonial varieties of English is Germany's Ruhr Area. The speakers originate from multilingual areas where their second language (L2) Englishes have been shaped by language contact (cf. Hundt \& Schreier, 2013), resulting in indigenisation and nativisation. Migration to the Ruhr Area then results in what we may call secondary language contact in that it follows a previous process of language contact, that had taken place in the original home country of the migrating individual, and in that it may be supplementary, adding to and extending the preceding mechanisms and outcomes.

In new ecologies of super-diversity, language uses and preferences change, and secondary language contact leads to changes in the original L2 Englishes through novel selections of linguistic features made by the multilingual speakers.

\section{The Ruhr Area and Immigration}

The Ruhr Area is located in the German federal state of North Rhine-Westphalia (NRW). In the past, the area had been characterised by a thriving mining and iron and steel producing industry (Friedrichs, 1996, p. 135), mostly located in and closely around the main cities that had developed as a result of industrialisation and urbanisation: Bochum, Dortmund, Duisburg, Essen, and Gelsenkirchen, and in the peripheral and smaller cities of Bottrop, Hagen, Hamm, Herne, Mühlheim an der Ruhr, and Oberhausen. 


\subsection{Major Immigrant Communities in the Ruhr Area}

The Ruhr Area has a rich history of migration, much of which started out as labour migration, initially, in the second half of the $19^{\text {th }}$ century, from various areas of Germany to the southern Ruhr Area, then, at the end of the $19^{\text {th }}$ century, "predominantly from the eastern parts of the German Reich and from Poland" (Friedrichs, 1996, p. 135). To meet the exceptional labour demand at the end of the 1950s, a series of so-called 'Anwerbeabkommen' (bilateral recruitment agreements) were signed with Italy (1955), Spain and Greece (1960), Turkey (1961), Morocco (1963), Portugal (1964), Tunesia (1965) and finally with former Yugoslavia (1968). Although this policy came to an end in 1973, following the international oil crisis, in-migration has continued to be high ever since, particularly when political unrest in developing or newly industrialising countries resulted in waves of refugees arriving as asylum seekers from the 1970s onwards.

Today, the Ruhr-Area's 17.5 million population (Note 1) includes vast numbers of individuals with a migration background, many of them being the offspring of the above mentioned original migrant workers. Often, they have obtained German citizenship and are now statistically covered as "Germans with migration background" (e.g., Bundesamt für Migration und Flüchtlinge 2011). Census data available for NRW document naturalisation in 2011 as follows: 18,379 Europeans, 3,622 Africans, 572 individuals from the Americas, 6,429 Asians (which includes the Near, Middle and Far East), and a number of individuals from Australia, Oceania, stateless and unclear cases obtained German citizenship, amounting to a total of 29,357. (Note 2) In addition, NRW was home to inhabitants with non-German citizenship in 2011 as follows: 1,485,509 Europeans, 74,816 Africans, 22,732 individuals from the Americas, 186,659 Asians, and 1,578 individuals from Australia. (Note 3) These figures include individuals from the former recruitment countries as follows: 540,976 Turkish, 132,723 Polish, 121,561 Italians, 85,266 Greeks, 35,232 Portuguese, 33,053 Spanish, 32,462 Moroccans, 6,811 Tunisians, and 5,783 from former Yugoslavia (figures refer to inhabitants registered in NRW as of 31.12.2011).

The numerical significance of these individuals has, of course, resulted in a vast amount of literature that describes the sociological (e.g., Bade, 2003) as well as the linguistic (e.g., Bernhard \& Lebsanft, 2012) history and current situation. English speakers, by contrast, have not been a focus of research so far, despite the recent increase of in-migration of individuals who originate from countries in which English is the sole or co-official language.

\subsection{Diasporic English-Speaking Communities in the Ruhr Area Today}

At the time of the 2011 census, 14,659 individuals whose main citizenship is from a nation in which English serves as a (co)official language were registered in the major cities of the Ruhr Area. Besides 4,018 (27.4\%) individuals who originate from countries where English has traditionally been spoken as a first language (L1), the vast majority immigrated from former British colonies. Of these, 5,070 (34.6\%) came from countries on the Indian subcontinent, 5,027 (34.3\%) from the African continent, and 544 (3.7) from various nations located in Asia. (Note 4)

Figure 1 illustrates how L1- and L2-speakers of English are distributed across the major cities of the Ruhr Area. It documents that the cities of Dortmund and Essen stand out in that they attract more English-speaking migrants than the others. Within the two, migrants from the Indian subcontinent and from the African continent have very similar shares. However, Dortmund is home to more L1-speakers of English than Essen. Of interest are also Hamm, Herne and Mülheim. Hamm and Herne, two smaller cities, do not seem to attract African immigrants very much, but migrants who originate from the Indian subcontinent are relatively overrepresented. In Mülheim, on the other hand, the share of Africans is significantly higher than in the other cities. 


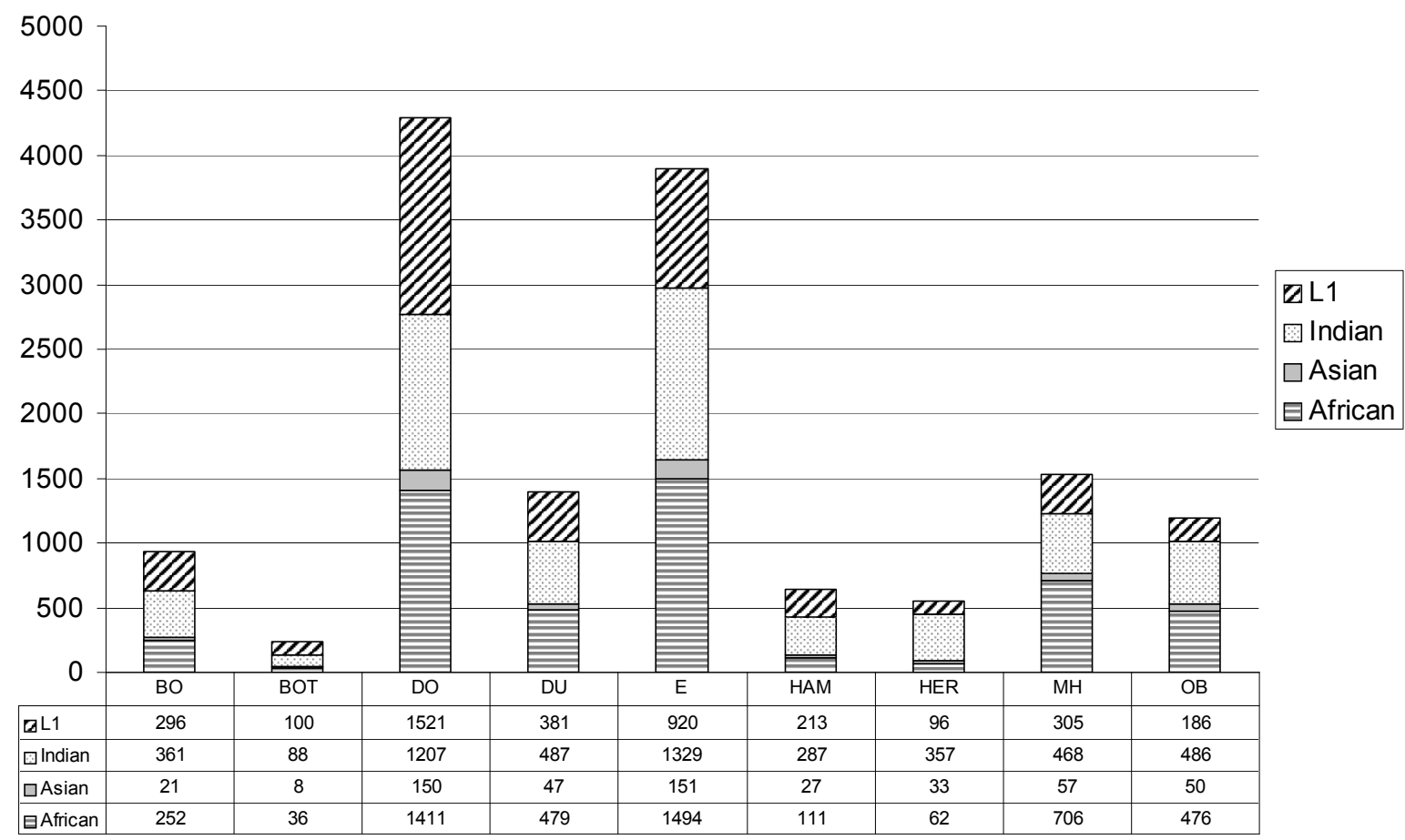

Figure 1. Immigrants by region of origin (Note 5)

A closer investigation of the residential preferences and patterns of the various communities revealed significant differences between those who have migrated from the African continent and those who have their origins in Asia or on the Indian subcontinent. Whilst the latter live scattered across the individual cities, Africans tend to reside in close-knit neighbourhoods, mainly in inner city areas of the larger cities. In Bochum, these are Langedreer, Hattenscheid-Höhtrop, Innenstadt, and Langendreer West, in Dortmund Innenstadt West, Innenstadt-Nord, and Scharnhorst, in Duisburg Kasslerfeld, Hochfeld, and Neudorf. In Essen, Africans mostly prefer the northern areas Dellwig, Borbeck-Mitte, Altendorf, Altenessen-Nord, and Altenessen-Süd, but also the inner city Stadtkern. For Mülheim, informants reported that Africans are scattered across the city, with some focus around the city centre, and in Oberhausen there is a preference to reside near the train station. (Note 6) These observations confirm Blommaert's $(2010$, p. 7) observation that "new migrants typically settle in older immigrant neighbourhoods, which thus develop into a layered immigrant space, where resident ('old') immigrants often rent spaces to newer, more temporary or transient groups [...]".

The residential preferences, and the associated tendency to form networks or not, seems to also be reflected in the language preferences that were observed in and reported by members of the various migrant and diaspora communities. Immigrants from Asian countries or from the Indian subcontinent often have a limited proficiency in English. The latter (e.g., Tamils from Sri Lanca) had frequently entered Germany as refugees with a low educational profile that did not include English. Others arrived with a particular vocational background that facilitated their immigration, e.g., as nurses, who have always been in strong demand. This is the case with many Filipinas, who then typically use German at their workplace. Yet others immigrate following marriage to a German, which often results in the use of German as a home language, even if proficiency in German is relatively low at the time of immigration. The social networks (Milroy, 1980) of all these individuals do not foster the use of English.

The remainder of this paper focusses on the African immigrant communities in the Ruhr Area, whose close-knit communities result in a maintenance of English as a main medium of communication, particularly in the first generation.

\section{Researching Super-Diversity in the Ruhr Area's African Diaspora Communities}

Given its ethnic and, hence, linguistic diversity, the Ruhr Area is certainly one in which recent patterns of immigration have led to forms of diversity that go beyond ethnicity and country of origin, as Vertovec (2007, p. 1205) points out. Diversity itself has become diversified by a number of additional factors: 
Such additional variables include differential immigration statuses and their concomitant entitlements and restrictions of rights, divergent labour market experiences, discrete gender and age profiles, patterns of spatial distribution, and mixed local area responses by service providers and residents. Rarely are these factors described side by side. The interplay of these factors is what is meant here, in summary fashion, by the notion of 'super-diversity'.

Recently, sociolinguistics has made use of the term, which originally developed in Cultural Studies, to account for the fact that "[m]igration makes communicative resources like language varieties [...] globally mobile" (Blommaert \& Rampton, 2011, p. 3). As Blommaert (2010, p. 8) finds, "[t]he repertoires of new migrants often appear to be 'truncated': highly specific bits of language and literacy varieties combine in a repertoire that reflects the fragmented and highly diverse life-trajectories and environments of such people". For a West African immigrant, for example, this may involve using a combination of one or several African vernaculars and a West African variety of English, but also a form of the 'host' language that is shared as a lingua franca with members of other immigrant communities (e.g., the Turkish).

The super-diverse character of the Ruhr Area implies that the area is also characterised by language contact with other postcolonial Englishes (e.g., Indian English, Nigerian English, or Cameroon English). Frequently, and particularly at the early stages of immigration, English is furthermore used as a lingua franca for interaction with the local German population and with other, mainly English-speaking migrants, and hence Interactions across Englishes (Meierkord, 2012, p. 2), in which different Englishes potentially merge towards new emergent linguistic systems, abound.

\subsection{Data and Methodology}

As Blommaert (2010, p. 12) explains, the seemingly chaotic character of such super-diverse ecologies frequently escapes traditional approaches, concepts, and methods, as individuals' linguistic repertoires can no longer be understood as consisting of a set of clearly defined and separable languages. Rather, these speakers utilise a collection of mobile semiotic resources, which comprise "concrete accents, language varieties, registers, genres, modalities such as writing" (Blommaert, 2010, p. 102). The "complex patterns of shifting and mixing" of these linguistic resources can, as a result, not adequately be captured using established linguistic notions such as code-switching. In fact, Meinhof (2009) as well as Blommaert \& Rampton (2011) suggest that super-diverse contexts of migration be best studied ethnographically. The data reported on throughout this paper originate from various subsequent data collection activities, which culminated in exactly such ethnographic fieldwork.

Our initial set of data, used to establish the residential patters of the respective communities reported in 2.2, results from visits to local African, Asian and Indian businesses, during which individuals working in the shops, restaurants, and call centers were approached for information. Once contact had been established, individual shops were re-visited to conduct ten semi-structured group interviews, each involving two research assistants and at least two respondents, to elicit information as regards the language preferences in the various communities. At the same time, following Shohamy \& Gorter's (2009) approach to linguistic landscaping, photographic documentation of visual multilingualism evident from posters displayed inside and outside businesses was carried out.

Simultaneously, Bridget Fonkeu immersed herself in the Cameroonian community, of which she is a member. A total of 58 Cameroonian migrants were visited in their homes and associations, to investigate their language preferences through semi-structured acquaintance interviews (Garton \& Copland, 2010) and through participant observation and recordings of spontaneous conversations.

\section{Language Use in the Ruhr Area's African Communities}

The Africans' migration histories, their subsequent living conditions, and their linguistic ecologies are very diverse. Informants in our interviews had arrived on medical or study grants, or simply to earn money to later start a business back home. As many eventually decided to permanently stay in the area, they tend to have family and friends in Germany. Whilst ties to their respective home countries vary, all interviewees reported to maintain links to African communities in Germany, which form significant parts of their individual social networks and hence are likely to influence their linguistic preferences.

\subsection{Narrated Language Preferences in the African Communities}

The fact that most African immigrants have arrived from West African countries has implications as regards the varieties of English that they bring with them. West Africa is characterised by the fact that pidginised varieties exist alongside more standard varieties of English. In Cameroon, for example, Cameroon English (CamE) and Cameroon Pidgin English (CPE) are both spoken widely (cf. Schröder, 2003; Anchimbe, 2006). CPE functions 
as a language of trade, education and the mass media at local and regional level, "but it is also evident at the national (e.g., mass media, political campaigns) and international levels (communication with other Africans" by anglophone as well as francophone Cameroonians, albeit to different degrees (Schröder, 2003, p. 181). Similarly, Simo Bobda \& Wolf (2003, p. 106) find that CPE is used in all domains except for parliament, newspapers, novels, records, and for teacher-student interaction outside the classroom and that it continues to spread in the new millenium. Attitudes towards CPE tend to be generally positive among the anglophone part of the population, whilst francophones seem to have more mixed feelings towards the variety (Simo Bobda \& Wolf, 2003, p. 111). This positive attitude towards CPE or other West African pidginised varieties is particularly strong in the diaspora. All interviewees had a knowledge of a pidginised variety of English, whilst at the same time not being multilingual in the various local vernaculars of their respective home countries. They reported to speak English in the home context, often Pidgin English (Note 7), which they described as being "like home" (see quote (2) below), and code-switching was said to be a frequent element in their interactions.

The following quotes (Note 8) from our interviewees' comments illustrate the complexity of their linguistic behaviour in the new linguistic ecology. Quote (1) explains the super-diverse nature of the immigrant communities, when the interviewee describes language use in multi-national meetings of the wider African community. As this community is very diverse, with members from anglophone (e.g., Nigeria, Ghana and parts of Cameroon) as well as francophone (e.g., Guinea, Congo, parts of Cameroon) African states, linguistic choices need to be negotiated to allow the communication of formal affairs.

(1). Because Africans, they speak French and English. So I can communicate ehh, I said the kid who are born here, but I can communicate very easy with the African, because they can speak French. Even those who speak French, they will speak English. So, even when we have a meeting, we have our café meeting and tomorrow we have every Mittwoch meeting, so I translate to the African, who don't understand English like the Guinée, they don't understand English. They're from Congo they doesn't understand English or when the English speaking, they dominate this organisation. So when they speak in English, I have to translate it in French to people who speak French. (Joe, Cameroonian male, Note 9)

As illustrated in the quote above, the dominant group usually determines the language used for formal meetings. However, it is common that English, Pidgin English, French, German, or indigenous languages are used and mixed in the course of these meetings, which reflects the super-diverse ecology on a micro-scalar level. While all official deliberations at such meetings are carried out in standard French and English, Pidgin English is reserved for informal interactions such as communication or discussions among friends (cf. Fonkeu, 2011), as quote (2) illustrates.

(2). Yea, mostly English and then Pidgin, too, they go hand in hand. You cannot just say English most@ at least the most Pidgin is like home, you are at home like a native thing, feel free with this person to speak Pidgin. [...] I know that if I see him, I can speak Cam-Cameroon English to you, eh, Pidgin, to him because I know he's a Cameroonian (.). Then if I see him, I can speak Nigerian Pidgin to him cause he is a Nigerian yea so I'm- and I happen to know the, the two. (Leyla, Nigerian female)

This speaker, a Nigerian born in Cameroon, emphasises the importance of Pidgin English as a language of solidarity among Cameroonians and other West Africans: Pidgin English helps the speakers negotiate their entrance into a particular social group (cf. Anchimbe, 2010). In the home countries, CPE and Nigerian Pidgin English serve as social indexes on a variety of different levels. The choice of either a pidginised or a standard variety of English reflects a speaker's level of education or social class. Students and scholars will tend to speak the standard variety in school or at University, and people of higher social status will mostly speak the standard variety to people of lower class background, except they are friends or family members. In the diaspora however, the use of Pidgin English, although it usually indexes belonging to a lower social class, expresses closeness and group membership.

Quote (2) also contains a reference to one of the linguistic outcomes of super-diversity. These communicative contexts are characterised by the mixing of different varieties of pidginised and standard Englishes, so that in the diaspora of the Ruhr Area, CPE and Nigerian Pidgin frequently merge into a hybrid Pidgin. In informal gatherings in the cellars (Note 10) of Duisburg, Mülheim, Essen and Dortmund, for example, it is difficult to predict what language will be spoken when Cameroonians meet with other immigrants from Ivory Coast, Nigeria, Senegal and the Congo. The language of choice will eventually be that of the most influential person present at the meeting, for instance someone who is in possession of very important details, such as where to find a job or other socio-economic information. 
German as an additional linguistic resource only plays a minor role for many first generation West-African immigrants, who often find it difficult to acquire the language, as they are pressured by their various obligations as quote (3) indicates.

(3). Because first we have so many things (.) in our head which disturbs us from (.) learning an extra an ah an an additional language yeah. Because like now as I'm sitting here, I have so many project in my head. But may be like you, you just think about yourself. You don't have anybody who to take care of. Like me, I take care of like uh several other people. Several other people. I make sure like they go to school they have what to eat, they have where to stay is under my own control. (anonymous Cameroonian female)

The quote illustrates the complexity of the first-generation immigrants' socioeconomic realities. Their well-being depends on many different variables, such as economic prosperity or social obligations to the family back home:

Security and economic benefit are at the heart of the decision to migrate, which is not primarily taken by an individual but by the extended family. The family decides in favour of persons who have shown themselves to be reliable and purposeful and who have often already completed studies in Cameroon. The family supports the migrant before and shortly after migration, pays the costs incurred, and expects remittances in return as a contribution to the improvement of the socio-economic situation of the family as a whole. (GTZ, 2006, p. 6)

The resulting obligation to achieve a stable financial standing adds to the pressure experienced by migrants (cf. Fleischer, 2007) and influences the learning process of the host culture's language. The migrants' occupation with securing their income often results in a lack of time to formally learn German, which in turn frequently leads to predominantly informal language acquisition, as is indicated in the next quote.

(4). And then they don't, I don't really know Deutsch, I'm just (.) I, I bite it. I just learn to say half, half Deutsch, I don’t-@@@@ this cot an nail Deutsch.@@@ I wollen lernen Deutsch for my, my, little, this little girl

$[\ldots]$

Yea, that's why I said I do kot an nail. You know how they call kot an nail this (.) they call it eh street Deutsch@@@ half halfDeutsch that you pick here and there. Sometimes it doesn't really make meaning, but they can really understand (Leyla, Nigerian female)

Our informant here finds that her basic knowledge of German, or kot an nail (Pidgin English for cut and nail, Note 11) German as she calls it, suffices for her to get on with her life and her business. (Note 12) This reflects the fact that each individual has his/her own reasons for migrating (cf. Fleischer, 2007). Whether an individual migrated for educational purposes, to make quick money to return home and start a business, or to migrate permanently and find a better life in the diaspora constrains her/his attitude towards learning the language of the host country. For a migrant whose aim it is to make quick money and leave, learning standard German is not deemed necessary.

The linguistic performance of our informant in the above quote furthermore illustrates that first-generation English-speaking West Africans in the Ruhr Area continue to use language(s) in the way they would do in their home countries. The speaker code-switches between Pidgin English, standard English, and German, as is clearly visible from expressions such as $I$ bite it, and the Pidgin English kot an nail. The former expression is a calque, originating from the indigenous cultures and languages and derived from the Pidgin English a jus bit am here an $d e$ ('I just bite it here and there'), which indicates an act of 'selecting things randomly'. It is meant to indicate that the speaker picks up or selects a number of German words and phrases at random, without approaching the new language systematically.

It is particularly this practice which is highly evident in the language use observed in written and spoken language. The following section discusses how the language preferences narrated above are reflected in factual written language use in the Cameroonian diaspora, as represented in signs and posters found outside and inside shops and other businesses and in spoken interactions, both formal and informal.

\section{Language Practices in the Cameroonian Diaspora Community}

Immigration from Cameroon to Germany is motivated by diverse factors and follows different purposes, but political and economic factors are at the heart of most of the decisions to migrate. Following the Operations Villes Mortes in 1991, the Franc CFE was devaluated and salaries were drastically reduced. This greatly limited the chances of sustainable livelihood for Cameroonians, since employment opportunities were lowered and even highly educated young Cameroonians were left unemployed. As a result, the bush faller philosophy, in which migration is considered highly lucrative, developed. Bush faller in CPE refers to a successful immigrant living in Europe, America or in any other part of the world and is strongly associated with prosperity, which is what a 
Cameroonian hopes to achieve abroad (cf. Fleischer, 2007; Pelican, Tatah \& Ndijo, 2008; Meierkord \& Fonkeu, 2013). Initially, the USA, Germany, Italy and the Netherlands were the target countries of choice. However, as the crisis persists, Cameroonians today are ready to migrate to any country, and bush falling is even taking place towards South Africa, Eastern Europe and China.

As the Cameroonian migrant community in the Ruhr Area is a relatively young one, contact between Cameroon English or Cameroon Pidgin English and German has a short history and so far been less intimate. As Thomason (2001, p. 70) explains, the situation characterising the first immigrant generation mostly results in borrowing at the level of the lexicon only. (Note 13) Sankoff (2001, p. 638) describes this process for migrant communities:

When a common second language is learned and used by a group of people - whether immigrants or by virtue of the introduction of a new language to a resident population - they often find themselves introducing second-language lexical items into conversation with fellow bilinguals in their original first language. Such items [...] are clearly the route for the later adoption or integration of these lexical items as loan-words in the immigrant or minority language.

In fact, exactly such integration of L2, German, vocabulary is documented by our data.

\subsection{English in Super-Diverse Posters}

Different from what is the case with the traditional immigrant communities in the Ruhr Area, Cameroonians (and also the other L2-English-speaking communities) are such a small minority that not much of their languages is visible in public space. Similar recent immigrant groups with a low level of stability have been found to "revert to highly unstable forms of written language, mixing English and Dutch and betraying non-native pronunciation of words", as Blommaert (2010, p. 10) observed with Nigerians in Belgium. Such inconstant writing is also frequently found on posters placed in and outside of the shops that cater for the African communities.

The windows of Cameroonian-managed shops tend to display posters that advertise products, parties, or meetings relevant to the community which the business mainly caters for. Figure 2 displays two of these. They were photographed outside a shop managed by a Cameroonian in Essen. The one on the left provides information about a music and dance event to be held in Aachen. It is largely in English except for the date (Frei $25 \mathrm{Mai}$ ) and the address (Theaterstraße 17 Aachen), both of which are given in German. The date is interesting in that its format diverges from the regular German preferences, which according to Duden (Bibliografisches Institut, 2013) would be Fr. 25. Mai, Fr. being the abbreviation for Freitag ('Friday'). The poster displayed on the right is a product advertisment, which is mostly in French except for the brand name Dark and Lovely and the slogans (e.g., My style, my way). It is also of particular interest as it is indexical of the transnational character of the community. The poster is displayed worldwide in exactly the same design. In total, the shop exterior is indexical of the formal linguistic repertoire of the Cameroonian community, in that it includes and mixes Cameroon's two official languages, English and French, and the language that dominates in the diaspora, German, each largely conforming to the orthographic norms of the standard languages.


Figure 2. Posters outside a Cameroonian-owned shop 
Inside the shop, the posters address various audiences and reflect the full spectrum of languages available in the linguistic ecology of the migrant community. Most are in English, some in French, and many integrate German and Cameroonian vernacular languages. They furthermore diverge from the externally mounted ones as regards the occurrence of non-standard orthography.

Figure 3 displays a selection of these posters. The one on the left is an example of written communication of one of the Cameroonian cultural associations. It had been put up by the Bakossi Cultural and Development Association (BACDA), an association maintained by members of the Cameroonian tribe Bakossi. It is mainly in English (using standard orthography), except for the address in Essen, which is mentioned in German and follows the German conventions for formatting addresses. Importantly, the poster also integrates words from the Bakossi language (Bakossi and ngone, a type of dance) and the Duala language (makossa, also a type of dance). These words as well as the acronym $B A C D A$ will probably only be understood by Cameroonians and index the shop owner's social identity.
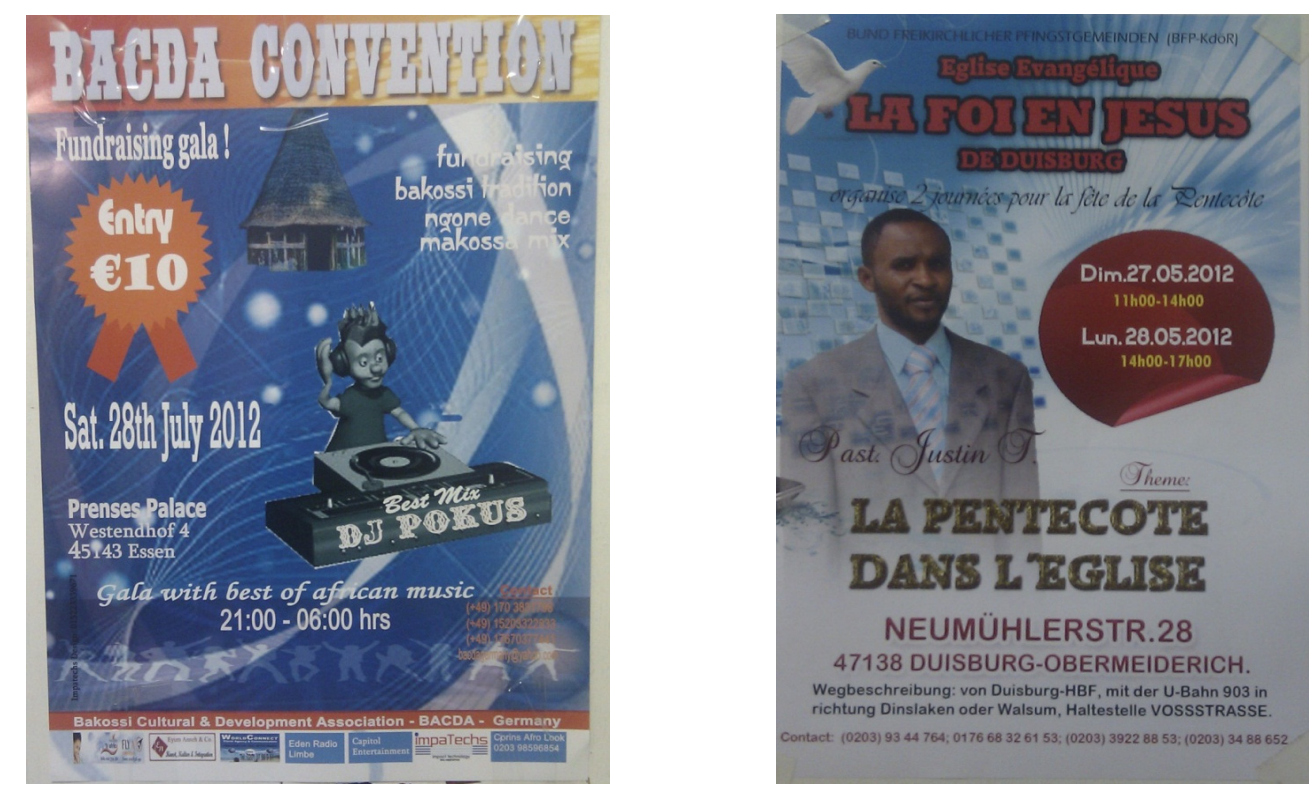

Figure 3. Posters inside the shop

The poster on the right mixes German and French and informs clients about activities of a particular church community. It is directed at a francophone audience, and the sermon or talk advertised can be expected to be in French, since both the title and the dates are given in French. However, the header of the poster, which reads Bund Freikirchlicher Pfingstgemeinden (association of free pentecostal church communities), and the bottom half, which provides the venue's address and gives directions to it, are both in German. In this case, there is some divergence from the standard German orthography: in the description of the directions richtung ('in the direction of') would normally be capitalised as Richtung. The French passages follow standard French orthography.

In sum, the bottom-up signage displayed inside the shop contributes to the creation of West-African-ness through the use of the standard official languages, English and French, which create links to Africans of a variety of countries of origin. Whilst vocabulary originating from the local vernacular languages is integrated into the English-language posters, Pidgin English does not play a role in this written genre.

\subsection{Diasporic Cameroon Pidgin English and Cameroon English in Spoken Genres}

The complexity of the processes characterising the use of L2-Englishes and other languages in super-diverse migrant communities is even more evident in the spoken language behaviour of the community's members, where especially borrowing abounds. The following examples illustrate this process of borrowing (borrowings are indicated by italics in the examples), which is particularly pronounced in CPE as documented in examples (5) and (6). 
(5). Leave me so ma sister na wahala for ma vermiete di man

('I bet you my sister it has been a very trying period, as our landlord')

don worry wi soteh we don decide for commot leave eh house.

('gave us so much trouble so we decided to quit our apartment.')

Na Turkei man weh e di check every move weh ee

('He is a Turkish landloard who checks on every move')

ee locateur dem make.

('his tenants make.')

In example (5), the German vermiete (an approximation of Vermieter) and Turkei (again an approximation, this time of Türkei) reflect the current contact with the German language. Both do not, however, occur to fill lexical gaps, as CPE possesses the words lan lod ('landlord') and Turki ('Turkey'). (Mesolectal CPE would normally refer to a Turkish person by using the expression na man from Turki, and Turkish man would be used in the acrolectal variety.) Another lexical item, the French word locateur, on the other hand reflects the mixed language status of $\mathrm{CPE}$ and the contact with and influence of Cameroon's dominant official language, French, mentioned above.

(6). A go cook foofoo and eru. A get some eru

('I intend to prepare fufu and eru. I still have some eru')

for house weh dem bi send am from payé.

('at home, which they (my parents) sent from Cameroon.')

Dis Christmas sef no go fine for me at all, a di bolo.

('There is no celebration for me this Christmas as I have to work.')

Na only Sylvester weh a deh free.

('Only New Year's eve is a day off.')

Example (6) is even more complex as regards the origins of the various borrowings contained in it. The passage includes the French payé, which is not unexpected in CPE because of the francophone heritage in Cameroon. The example also illustrates the integration of local vernacular items for food: foofoo is a staple food made from Cassava dough. Eru is a green wild leaf that has become a popular vegetable because of its high nutritive value, and which is normally cooked together with spinach as a moisturiser. Again, this strategy of borrowing from the local vernaculars is also common in CPE spoken in Cameroon. Additionally, however, there is again an indicator of the prevailing language contact with German, which is revealed by the item Sylvester. In this example, the German word documents the influence of German culture and is borrowed to make up for a lexical gap: in CPE, there is no expression for new year's eve (which might, however, be borrowed into CPE by highly acrolectal speakers). Rather, this would be referred to by paraphrasing as de dai bifo niu yia.

Our observations so far also indicate that whilst borrowing from German is very common in CPE, as seen in (5) and (6), this occurs less frequently in CamE. This difference is likely to result from the fact that Cameroonians use CamE for more formal purposes and with an exonormative British model in mind. However, examples (7) and (8) reveal that borrowing into CamE is not entirely uncommon. Both are indicative of the migrants' retention of practices they also employ in Cameroon in that CPE words have been borrowed and integrated into the CamE passages.

(7). Members who had not paid the 25 Euros for Mr. X's cry die were called up to do so. They were asked to meet the financial secretary to meet up their obligation.

In example (7), the phrase cry die literally means 'crying the dead'. It refers to the funeral celebration, which in Cameroon consists of two phases: initially ritualistic mourning takes place, which involves participants actually crying and singing a funeral dirge. Immediately following the dirge, in a second phase, dancing and singing celebrate life to acknowledge that the dead is gone but the living have to go on with their lives. The CPE expression Pikin planti in example (8) literally means 'the baby's plantain' and refers to the birth celebration. The expression connotes a delicious pot of plantain, spiced with a lot of palm oil, which is traditionally prepared as a highlight to the celebration. 
(8). Mr. X's wife has given birth to a bouncing baby girl and so he has decided to celebrate on the xx of January 2011. The meeting of January will therefore take place in Mr. X's residence at Kaiserplatz. We will have a brief meeting and then go straight into the pikin planti.

Example (8) furthermore indicates that borrowing from German into CamE does take place but is highly limited. In the example, a place name, Kaiserplatz, occurs, which could not be translated for obvious reasons.

In sum, language contact in the new residential area is reflected both in spoken CamE and CPE, in the form of borrowings from German. Whilst CPE still possesses borrowings from French and the vernaculars, loan words from French seem to be giving way to lexical loans from the German language in CPE: of the seven loan words found in the CPE passages recorded at meetings, six are German and only one is French. This might indicate that language contact in the new residential area starts to result in a replacement of lexical items that were borrowed into CPE as a result of the language contact ecology in Cameroon itself. By contrast, the CamE data reveal a different picture. In the diaspora, CamE retains borrowings from French, CPE and the vernacular languages. Of the seven loans in our data, just two are from German (and arguably proper names as discussed above) whilst two more are French and three from CPE. Although loans from the vernaculars are not documented in our data, lexical items referring to food, e.g., foofoo, eru, dodo, and egusi would be borrowed in CamE just as in CPE, as our interviewees explain.

\section{Conclusion}

The narrated language choices as well as the factual language uses documented on posters and in authentic face-to-face conversations testify that the contact Englishes that immigrants introduce to the Ruhr Area are indeed subject to secondary language contact with German as well as to dialect or variety contact, i.e. contact with various other Englishes. Having developed out of language contact in their speakers' home countries, postcolonial Englishes already possess lexicons that draw on multiple sources, albeit comprising primarily of English lexical items. As regards, for example, the Englishes of Cameroon, Simo-Bobda (1994) and more recently Wolf \& Igboanusi (2003, p. 75) explain that CamE draws on indigenous languages, CPE, and French as its main sources of borrowing, reflected in the form of "direct loans, calques and hybrids" (Wolf \& Igboanusi, 2003, p. 78). The history of CPE has led to it additionally including word stock of Portuguese and German origin (Anchimbe, 2012, p. 3).

In the diaspora, the processes of borrowing are even more complex. After having moved to the Ruhr Area, speakers often maintain ties to their original home country and are in contact with their original vernaculars via phone calls and visits to their relatives at home and via interaction with fellow nationals. At the same time they interact with speakers of other varieties of English and, of course, with German and its varieties. As a result, features of various Englishes combine with French, African vernaculars and German elements to blend into a new code, both in written and spoken genres.

These observations indicate that the realities of Englishes today are considerably different from what was the case when the World Englishes model, in terms of Kachru's (1985) Three Circles, was originally conceived in the 1980s. Given its history and original aim, that of discussing L2 varieties of English as varieties in their own right, the World Englishes paradigm has traditionally been concerned with describing postcolonial L2 varieties of English as they are used within the habitats in which they emerged, for example Nigerian English in Nigeria or Singapore English in Singapore. However, as Mufwene (in Blommaert, 2010, p. xi-xii) cautions us, today's patterns of mobility have been making "static geolinguistics clearly out of date". In fact, the realities of migration result in interactions-across-Englishes, in which the different Englishes potentially merge in that their individual features "become available for selection by participants in such interactions" (Meierkord, 2012, p.8). Similarly, Mair (2013, pp. 325-6) proposes to envisage English "not as a bundle of separate varieties (which usually have a regional base and can be decontextualised and described by listing their phonetic, morphosyntactic and lexical properties) but rather as a pool of standard and non-standard features of varying and fuzzy regional reach" (italics in original, $\mathrm{cm}$ ). Further research is indispensable to further combine these notions with the one of polylanguaging, i.e. "the phenomenon that speakers employ linguistic resources at their disposal which are associated with different 'languages"” (Møller \& Jørgensen, 2013, p. 25), looking beyond languages as bounded entities, and to fully describe how the social circumstances of diaspora communities result in their members blending elements from their large repertoire of linguistic resources into a new code that serves the diaspora's identity construction.

\section{Acknowledgements}

Publication of this paper has been supported by the German Research Foundation and the Open Access Publication Funds of the Ruhr-Universität Bochum. 


\section{References}

Anchimbe, E. (2006). Cameroon English: Authenticity, ecology and evolution. Frankfurt a.M.: Peter Lang.

Anchimbe, E. (2010). The place of the English language in the construction of a Cameroon anglophone identity. TRANS. Internet-Zeitschrift für Kulturwissenschaften 17/2008. Retrieved from http://www.inst.at/trans/17Nr/1-3/1-3_anchimbe17.htm

Anchimbe, E. (2012). Language contact in a postcolonial setting: research approaches to Cameroon English and Cameroon Pidgin English. In E. Anchimbe (Ed.), Language contact in a postcolonial setting: The linguistic and social context of English and pidgin in Cameroon (pp. 3-25). Berlin: De Gruyter Mouton.

Bade, K. J. (2003). Migration in European history. Oxford: Blackwell.

Bernhard, G., \& Lebsanft, F. (Eds.). (2012). Mehrsprachigkeit im Ruhrgebiet. Tübingen: Stauffenburg.

Bibliografisches Institut. (2013). Duden. Berlin: Bibliografisches Institut. http://www.duden.de/

Blommaert, J. (2010). The sociolinguistics of globalization. Cambridge: Cambridge University Press.

Blommaert, J., \& Rampton, B. (2011). Language and superdiversity: a position paper. King's College London: Working Papers in Urban Language \& Literacies, 70. Retrieved from http://www.kcl.ac.uk/sspp/departments/education/research/ldc/publications/workingpapers/70.pdf

Bundesamt für Migration und Flüchtlinge. (2011). Migrationsbericht des Bundesamtes für Migration und Flüchtlinge im Auftrag der Bundesregierung. Migrationsbericht 2011. Berlin: Bundesministerium des Innern.

Fleischer, A. (2007). Family, obligations, and migration: The role of kinship in Cameroon. Demographic Research, 16(13), 413-440. http://dx.doi.org/10.4054/DemRes.2007.16.13

Fonkeu, B. (2011). Multilingualism and language domains. An empirical study of the Cameroonian immigrants in the Ruhr area (Unpublished master's thesis). Ruhr-University Bochum, Bochum, Germany.

Friedrichs, J. (1996). Intra-regional polarization: cities in the Ruhr Area, Germany. In J. V. O'Loughlin, \& J. Friedrichs (Eds.), Social polarization in post-industrial metropolises (pp. 133-172). Berlin: De Gruyter.

Garton, S., \& Copland, F. (2010). 'I like this interview: I get cakes and cats!' The effects of prior relationships on interview talk. Qualitative Research, 10(5). 533-551. http://dx.doi.org/10.1177/1468794110375231

Gesellschaft für Technische Zusammenarbeit (GTZ). (2006). The Cameroonian diaspora in Germany. Its contribution to development in Cameroon. Eschborn: Deutsche Gesellschaft für Technische Zusammenarbeit.

Hundt, M., \& Schreier, D. (2013). Introduction: nothing but a contact language ... In D. Schreier, \& M. Hundt (Eds.), English as a contact language (pp. 1-17). Cambridge: Cambridge University Press.

Kachru, B. B. (1985). Standards, codification and sociolinguistic realism: the English language in the outer circle. In R. Quirk, \& H. G. Widdowson (Eds.), English in the world: Teaching and learning the language and literatures (pp. 11-30). Cambridge: Cambridge University Press.

Kouega, J.-P. (2008). A dictionary of Cameroon Pidgin English usage. Pronunciation, grammar, and vocabulary. Munich: Lincom.

Mair, C. (2013). Speculating on the future of English as a contact language. In D. Schreier \& M. Hundt (Eds.), English as a contact language (pp. 314-328). Cambridge: Cambridge University Press.

Meierkord, C. \& Fonkeu, B. (2013). Of birds and the human species - communication in migration contexts: English in the Cameroonian migrant community in the Ruhr are. In N.-L. Johannesson, G. Melchers \& B. Björkman (Eds.), Of butterflies and birds, of dialects and genres. Essays in honour of Philip Shaw (pp. 271-287). Stockholm: Acta Universitatis Stockholmiensis.

Meierkord, C. (2012). Interactions across Englishes. Linguistic choices in local and international contact situations. Cambridge: Cambridge University Press.

Meinhof, U. H. (2009). Transnational flows, networks and 'transcultural capital'. Reflections on researching migrant networks through linguistic ethnography. In J. Collins, S. Slembrouck, \& M. Baynham (Eds.), Globalization and language in contact: Scale, migration, and communicative practices (pp. 148-169). London: Continuum.

Milroy, L. (1980). Language and social networks. Oxford: Blackwell. 
Møller, J. S., \& Jørgensen, J. N. (2013). Organizations of language among adolescents in superdiverse Copenhagen. International Electronic Journal of Elementary Education, 6(1), 23-42. Retrieved from $\mathrm{http}: / /$ www.iejee.com/6_1_2013/IEJEE_6_1_m\%C3\%B8ller_j\%C3\%B8rgensen.pdf

Pelican, M, Tatah, P., \& Ndjio, B. (2008). Local perspectives on transnational relations of Cameroonian migrants. African Sociological Review, 12(2), 117-127. http://dx.doi.org/10.4314/asr.v12i2.49841

Sankoff, G. (2001). Linguistic outcome of language contact. In P. Trudgill (Ed.), Handbook of sociolinguistics (pp. 638-668). Oxford: Blackwell.

Schneider, E. (2007). Postcolonial English. Varieties around the world. Cambridge: Cambridge University Press.

Schröder, A. (2003). Status, functions and prospects of Pidgin English. An empirical approach to language dynamics in Cameroon. Tübingen: Narr.

Shohamy, E., \& Gorter, D. (Eds.). (2009). Linguistic landscape. Expanding the scenery. London: Routledge.

Simo-Bobda, A. (1994). Lexical innovation processes in Cameroon English. World Englishes, 13(2), 245-260. http://dx.doi.org/10.1111/j.1467-971X.1994.tb00310.x

Simo-Bobda, A., \& Wolf, H.-G. (2003). Pidgin English in Cameroon in the new millennium. In P. Lucko, L. Peter, \& H.-G. Wolf (Eds.), Studies in African varieties of English (pp. 101-117). Frankfurt a.M.: Lang.

Thomason, S. G. (2001). Language contact. An introduction. Washington, DC: Georgetown University Press.

Vertovec, S. (2007). Super-diversity and its implications. Ethnic and Racial Studies, 30(6), 1024-1054. http://dx.doi.org/10.1080/01419870701599465

Wolf, H.-G., \& Igboanusi, H. (2003). A preliminary comparison of some lexical items in Nigerian English and Cameroon English. In P. Lucko, L. Peter, \& H.-G. Wolf (Eds.), Studies in African varieties of English (pp. 69-81). Frankfurt a.M.: Lang.

\section{Notes}

Note 1. The latest census documented a population of 17.538.251, as of May 9, 2011 (cf. Landesbetrieb Information und Technik Nordrhein-Westfalen. Retrieved June 27, 2014, from http://www.it.nrw.de/statistik/z/daten/tab1_html.html

Note 2. Source: Einbürgerungsstatistik Nordrhein-Westfalen, Einbürgerungen von Ausländern nach Geschlecht und dem Staat der bisherigen Staatsangehörigkeit (98) - Gemeinden - Jahr, Information und Technik Nordrhein-Westfalen. Geschäftsbereich Statistik. Retrieved June 27, 2014, from http://www.landesdatenbank.nrw.de

Note 3. Source: Ausländerstatistik Nordrhein-Westfalen, Ausländische Bevölkerung nach Geschlecht und ausgewählten Staatsangehörigkeiten (85) der Welt - Land - Stichtag, Information und Technik Nordrhein-Westfalen, Geschäftsbereich Statistik. Retrieved June 27, 2014, from http://www.landesdatenbank.nrw.de

Note 4. We learnt during our fieldwork that those individuals who had come from countries such as Sri Lanka or Bangladesh frequently did not have a history of using English as a second language in their original home countries. Many had arrived as political refugees with only very limited formal education obtained in rural parts of their countries of origin.

Note 5. The following abbreviations have been used to refer to the individual cities: BO for Bochum, BOT for Bottrop, DO for Dortmund, DU for Duisburg, E for Essen, HAM for Hamm, HER for Herne, MH for Mülheim, and $\mathrm{OB}$ for Oberhausen.

Note 6. No clear patterns could be identified for the smaller cities, Bottrop and Herne.

Note 7. We use the term Pidgin English to refer to West African Pidgin Englishes whenever passages discuss aspects that Bridget Fonkeu holds to be shared across the various pidginised varieties in West Africa.

Note 8 . In addition to standard orthography, the following symbols are used: [...] indicates that passages from the interview have been left out, (.) and (..) indicate very brief and brief pauses respectively, italics are used to highlight non-English words, @ indicates laughter, and (xxx) indicates passages that were inaudible or impossible to transcribe. To preserve our interviewees' anonymity, all names used here are nicknames, chosen 
by the speakers themselves. In case a nickname was not available, names have been replaced by $X$, which is furthermore used to replace unwanted references to place names and dates.

Note 9. In the example, Mittwoch is German for Wednesday, and Guinée is French for Guineans.

Note 10. Cellars (English) or Keller (German) here refers to meeting points for African immigrants in the Ruhr area. They are located in the basement of most African shops and serve as refreshment spots and places where substantial information about the community can be obtained.

Note 11. The orthography used for CPE in this paper follows Kouega (2008).

Note 12. At the same time, a sizeable number of educated first generation migrants are motivated to have a full mastery of the German language, particularly if they wish to be employed in skilled positions.

Note 13. Further research will need to show whether language contact and bilingualism in the first generation are already sufficiently intense for borrowing to range on stage 2 ('Slightly more intense contact') on Thomason's (2001) borrowing scale. In this case, minor structural borrowing would also be expected, as well as borrowing of individual function words.

\section{Copyrights}

Copyright for this article is retained by the authors, with first publication rights granted to the journal.

This is an open-access article distributed under the terms and conditions of the Creative Commons Attribution license (http://creativecommons.org/licenses/by/3.0/). 